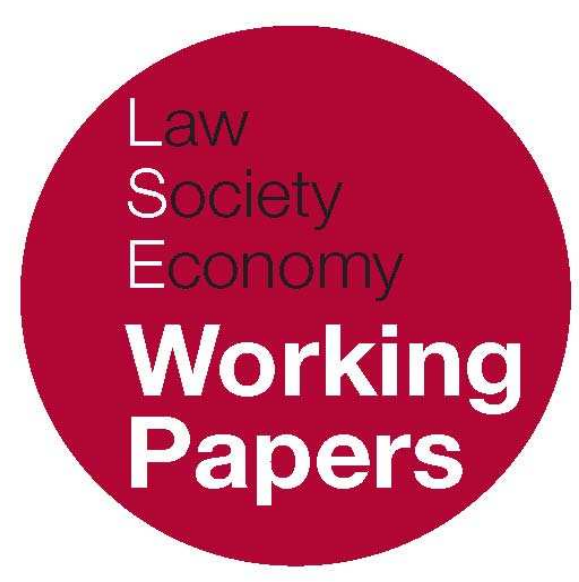

\title{
Private Law and the Public Sector's Central Counterparty Prescription for the Derivatives Markets
}

Joanne P. Braithwaite

LSE Law, Society and Economy Working Papers 2/2011 London School of Economics and Political Science

Law Department

This paper can be downloaded without charge from LSE Law, Society and Economy Working Papers at: www.lse.ac.uk/collections/law/wps/wps.htm and the Social Sciences Research Network electronic library at: http://ssrn.com/abstract $=1791740$.

(C) Joanne P. Braithwaite. Users may download and/or print one copy to facilitate their private study or for non-commercial research. Users may not engage in further distribution of this material or use it for any profit-making activities or any other form of commercial gain. 


\title{
Private Law and the Public Sector's Central Counterparty Prescription for the Derivatives Markets
}

\author{
Joanne P. Braithwaite *
}

\begin{abstract}
In the wake of the financial crisis considerable momentum has built-up behind proposals to extend central counterparty (CCP) clearing in the over-the-counter derivatives markets. However, the implementation of new rules is proving complex. This paper argues that one cause of this complexity is that the public sector is seeking to incorporate into legislation (and require the wider use of) a privately owned and operated risk management mechanism. As a matter of law, the paper argues that CCP clearing can be understood as a market-generated 'legal device'; in other words, one designed to support the markets by means of the interaction of various private law techniques. Following this analysis through, the paper highlights the benefits and drawbacks which derive from the legal techniques underlying CCP clearing (standardisation of contracts, asset-backing, netting, and so on) and argues that these qualities are inherent to the device. It concludes that the inherent capacity of CCP clearing gives rise to a qualitatively different set of challenges for policymakers than those arising from technical implementation, and it explains that both types of problem need to be addressed if the CCP prescription is to be effective.
\end{abstract}

\footnotetext{
* Law Department, London School of Economics and Political Science. With thanks to Professors Niamh Moloney and Hugh Collins for their comments on an earlier draft of this paper. Any errors are the author's own. The final version of this paper is forthcoming; see J.P. Braithwaite, 'The Inherent Limits of "Legal Devices": Lessons for the Public Sector's Central Counterparty Prescription for the OTC Derivatives Markets' (forthcoming, March 2011) European Business Organisation Law Review.
} 


\section{INTRODUCTION}

Traditionally regarded as an important but unglamorous part of the infrastructure of the financial markets, commentators have often subjected central counterparty (CCP) clearing to metaphors about plumbing. ${ }^{1} \mathrm{CCP}$ clearing services are operated by clearing houses such as LCH.Clearnet Ltd $(\mathrm{LCH})$ or ICE Clear Europe, which are authorised and supervised in the UK by the Financial Services Authority (FSA). ${ }^{2}$ The job of CCPs is to provide clearing services to members and exchanges, reducing risk and increasing efficiencies in the post-trade and presettlement period. How they achieve these important effects as a matter of law is one of the questions which is central to this paper.

As states and other regulators have considered their responses to the financial crisis, CCPs have come to assume a prominent place in the debate. Specifically, the recommendation that CCP clearing should be required for over-the-counter (OTC) derivatives, ${ }^{3}$ as a way of increasing transparency and stability in these markets, has been endorsed by the G20, the European Commission, the European Central Bank, the Obama administration, and HM Treasury and the FSA amongst others. On the basis of the shared features of these authorities' recommendations, I label this reform the 'CCP prescription' for the OTC derivatives markets. However, as I discuss below, this is not to downplay the important differences in detail between what various parties are proposing.

The providers of clearing services have responded swiftly to the opportunity presented by these recommendations, with some setting up clearing systems for OTC derivatives even before new rules had been published in draft form. As early as August 2009, at least seven clearing houses for CDS had already launched or were forthcoming: in the US (ICE US Trust, CME); the UK (NYSE LIFFE/BClear, LCH.Clearnet, and ICE Clear Europe); Germany (Eurex); and France (LCH.Clearnet S.A.). ${ }^{4}$

However, concluding from all this momentum that the CCP prescription is one of the more uncontroversial or straightforward elements of the public sector's legislative response to the financial crisis would be a mistake. In fact, settling the

\footnotetext{
1 For example, 'Counter Insurgency: The Craze for Clearing Houses' (27 June 2009) The Economist, (describing CCPs as 'part of the financial plumbing') at <http://www.economist.com/node/13905494> (all websites last visited 15 February 2011); 'Making a Stink; Credit Derivatives’ (1 July 2006) The Economist at <http://www.economist.com/node/7126393>; N. Aubry, 'Regulating the Plumbing of Europe' (2008) 23 Journal of International Banking Law and Regulation 578; and P. Wood, 'What Is a Central Counterparty in the Financial Markets?' (Allen \& Overy, 20 August 2009) noting the usual metaphors and expressing a preference for a comparison with cathedral columns, at <http://www.allenovery.com/ AOWEB/AreasOfExpertise/Editorial.aspx?contentTypeID=1\&itemID $=52783$ \&prefLangID $=410>$.

2 The regulatory framework for CCPs is discussed in B. Penn, 'Recognised Investment Exchanges (RIEs) and Recognised Clearing Houses (RCHs)' in M. Blair and G. Walker (eds), Financial Markets and Exchanges Law (Oxford: OUP, 2007).

${ }^{3}$ See the definition of derivatives generally and of OTC derivatives in the text to note 8 .

${ }^{4}$ European Central Bank/Eurosystem, 'Credit Default Swaps and Counterparty Risk' (August 2009 ) 77 at

$<$ www.ecb.int/pub/pdf/other/creditdefaultswapsandcounterpartyrisk2009en.pdf>.
} 
detail of new legislation to mandate further CCP clearing of OTC derivatives has turned out to be an extremely difficult task, involving technical decisions on a host of matters. The public debates thus far have addressed a range of such matters simultaneously, including what types of derivatives the reforms should cover, what qualities are needed for a derivatives contract to be 'clearing eligible', whether clearing should be mandatory or recommended, how non-cleared (or nonclearable) contracts should be regulated, where CCPs should be located, how many there should be, how they should be run, who should bail them out, and so on. Each of these details goes to the heart of how the CCP prescription will work and, if not confronted effectively, threatens to frustrate any new rules which policymakers produce.

Against this background, this paper focuses on the nature and capacity of CCP clearing itself and the consequences for the debate about the public sector's implementation of the CCP prescription. The emphasis in this paper is on the role of private law, which has featured less prominently in the debates than some other perspectives, ${ }^{5}$ but which offers valuable insights into the process of implementing this reform. The thesis which I advance in this paper is that:

1) Implementing the CCP prescription is proving complex in part because the public sector is seeking to incorporate into legislation (and require the wider use of) a privately owned and operated risk management mechanism. However the implications of incorporating mandatory CCP clearing into financial regulatory reform have not been addressed in a systematic way in the public debates, which have tended to ask 'how will this reform work?' rather than first dealing with the question of 'how does CCP clearing work?'.

2) CCP clearing is complex and can be analysed in different ways depending on the disciplinary perspective being used, but as a matter of law it can be understood as a market-generated 'legal device'; in other words, it is a process designed to serve the markets by means of the interaction of various private law techniques. Following this analysis through highlights not only the strengths but also the limitations arising from the underlying legal techniques (standardisation of contracts, asset-backing, netting and so on).

3) These strengths and limitations are inherent to the device. This means that they have to be recognised and managed upfront by policymakers

\footnotetext{
${ }^{5}$ For example, as compared to the disciplines of finance and economics which were well-represented at the 'high-level conference' organised by the European Commission on 25 September 2009 to conclude its public consultation on OTC derivatives markets. The agenda and materials from this conference are at $<$ http://ec.europa.eu/internal_market/financial-markets/derivatives/index_en.htm>. There has, of course, been input to the CCP debate from practising lawyers. See, for example, A. Glass, "The Regulatory Drive towards Central Counterparty Clearing of OTC Credit Derivatives and the Necessary Limits on This' (2009) 4(S1) Capital Markets Law Journal S79.
} 
intending to incorporate CCP clearing of OTC derivatives into their regulatory response to the financial crisis.

4) The inherent capacity of CCP clearing represents a qualitatively different set of challenges for policymakers compared to those arising from the implementation of the CCP prescription; however, both types of problem need to be addressed if the CCP prescription is to be effective.

In advancing these arguments, this paper is organised into three parts. The first provides the background to the CCP prescription, charting the problems which have been diagnosed in certain OTC derivatives markets in the wake of the financial crisis, the emergence of the official consensus behind an extension of CCP clearing, and the ongoing attempts to settle the detail of this reform.

The following part of the paper considers the function and capacity of CCP clearing. Contextualising CCP clearing alongside other 'legal devices' which facilitate market activity, I argue that the strengths and weaknesses of such devices are usefully highlighted by taking a private law perspective. I go on to consider, as a matter of English law, the legal techniques underlying CCP clearing as a way of investigating the capacity of this particular legal device.

The next part of the paper returns to the ongoing policy debates about the CCP prescription. On the basis of the preceding analysis, I suggest that it is helpful to isolate two different types of challenges confronting policymakers. The paper concludes with thoughts about how the debates about the CCP prescription may usefully proceed.

\section{THE CCP PRESCRIPTION}

The financial crisis which began in 2007 with, as Lord Turner has put it, 'an initial crack in confidence and collapse of liquidity's brought the international banking system to the brink of collapse and continues to have devastating effects on the real economy. Since then, a significant part of the debate about 'what went wrong'7 and what should happen now has focused on the OTC derivatives markets.

Derivatives are bilateral contracts in which the parties' rights and obligations are calculated with reference to a specified index, asset, interest rate, commodity or

\footnotetext{
${ }^{6}$ A. Turner, The Turner Review: A Regulatory Response to the Global Banking Crisis (London: FSA, March 2009), 27. George Soros states that 'the outbreak of the current financial crisis can be officially fixed at August 2007'. The New Paradigm for Financial Markets: The Credit Crisis of 2008 and What It Means (New York: PublicAffairs, 2008), xiii.

7 The title of chapter 1 in Turner, ibid.
} 
other metric. ${ }^{8}$ OTC derivatives are usually defined as those which are entered into privately rather than on an organised exchange. This is a useful definition, though in practice the distinction is not always this clear cut. ${ }^{9}$ The most important types of OTC derivatives are interest rate, credit, foreign exchange, equity, and commodities derivatives. As discussed below, new and proposed legislation mandating CCP clearing seeks to catch all types of OTC derivatives (exceptions in the legislation published so far turn on the identity of the contracting party, not the nature of the derivative in question). However, the momentum for this reform originated in the immediate aftermath of the crisis, when the debate focused on credit default swaps (CDS), a type of credit derivative.

Legally speaking, a CDS is a contract where the rights and obligations of the parties derive from the credit risk of a reference entity or asset. Under a CDS, a 'protection buyer'10 contracts with a counterparty and in return for a premium buys protection against particular credit events (which should be carefully defined in the contract). ${ }^{11}$ CDS emerged as a class of OTC product in the mid-1990s, and since then, the growth of the market has been staggering. ${ }^{12}$ However, by the outbreak of the crisis in 2007 various factors had made this market particularly fragile. The Turner Review, for instance, drew attention to the sheer size and complexity of the market and the fact that it is traded in an almost entirely Overthe-counter (OTC) fashion'.13

The extraordinary complexity which evolved in this part of the OTC derivatives market has now been widely documented. ${ }^{14}$ In particular, the use of CDS not in 'single-name' products, ${ }^{15}$ but as a 'building block'16 in complex securitisations which create new instruments with 'synthetic' exposure to a portfolio of assets, ${ }^{17}$ has become a hot topic for economists and other commentators considering the build-up to the financial crisis. For example, the

\footnotetext{
${ }^{8}$ For a more detailed definition of derivatives see J. Benjamin, Financial Law (Oxford: OUP, 2007), 65.

9 As demonstrated in E. Murray, 'UK Financial Derivatives Commodities Markets' in Blair and Walker (eds), n 2 above, 273-274.

${ }^{10}$ To use the term which is central to Benjamin's thesis of financial law. Benjamin, $\mathrm{n} 8$ above, 49-50.

11 The obligations of the protection buyer and seller under a single name CDS are helpfully set out in diagrammatic form in D. Rule, "The Credit Derivatives Market: Its Development and Possible Implications for Financial Stability' (June 2001) Financial Stability Review (London: The Bank of England), 118. See also the detailed explanation in 'What Are CDSs and How Are They Used?' in European Central Bank/Eurosystem, $\mathrm{n} 4$ above, 9-10.

${ }^{12}$ For example, the European Central Bank/Eurosystem note that the CDS market rose by 900 per cent in the three years prior to the end of 2007 by which point it had a gross nominal value of US $\$ 58$ trillion. European Central Bank/Eurosystem, 'OTC Derivatives and Post-Trading Infrastructures' (September 2009), 13 at <http://www.ecb.int/pub/pdf/other/overthecounterderivatives200909en.pdf>.

13 Turner, $\mathrm{n} 6$ above, 82.

${ }^{14}$ For example, see the 2009 European Central Bank/Eurosystem report which called CDS 'opaque credit risk instruments'. n 4 above, 4. The European Commissioner for Internal Market and Services, Charlie McCreevy, has commented of CDS that 'the opaqueness of these products leads to nasty surprises when things go wrong'. 'Time for Regulators to Get a Better View of Derivatives: Statement on Reviewing Derivatives Markets before the End of the Year' (Speech/08/538, Brussels, 17 October 2008). 15 Where CDS provide protection with respect to individual reference entities or assets. See Rule, n 11 above, 118-119.

16 ibid, 140 .

17 ibid, 120-121.
} 
proliferation of complex securitised products attracted detailed analysis in the Turner Review, ${ }^{18}$ and in 2009 the US Department of the Treasury stated that the risk characteristics of CDS used in asset-backed securitisations proved to be 'poorly understood even by the most sophisticated of market participants'.19 Elsewhere, one (lay) author has suggested that no one understood these complex structured products at the time, ${ }^{20}$ and even the most expert financial services commentators have resorted to magic-referencing metaphors in their attempts to convey the complexity involved. Howard Davies, for instance, talks of the 'complex alchemy' of securitisations, ${ }^{21}$ while Charles Morris (whose software company made tools for 'building and analysing [...] securitised asset pools' ${ }^{22}$ writes of how 'highly rated bonds magically materialize out of a witches' soup of very smoky stuff. ${ }^{23}$

CDS ultimately played a decisive role in the near-collapse of the American Insurance Group (AIG) which had to be bailed out by the US Government in 2008. ${ }^{24}$ This rescue was in part driven by the large net selling position the insurer had in the CDS market, as a counterparty to CDS of over US $\$ 400$ billion. ${ }^{25}$ Thus, had AIG collapsed in such a 'highly concentrated'26 market, it would have left very many 'protection buyers' without the benefit of their CDS contracts. As the European Central Bank/Eurosystem review put it, these counterparties would have instantly been forced to reappraise the value of the underlying corporate debt obligations [...] It was widely considered that the expected knock-on effects for the already destabilised financial system would have been far-reaching.'27

The collapse of Lehman Brothers (another major participant in the CDS market) also served to draw regulatory attention to the systemic risk posed by this deeply 'interconnected' market, ${ }^{28}$ and together these crises jump-started the debate

18 For example, see the discussion of the 'wave of financial innovation focused on the origination, packaging, trading and distribution of securitised credit instruments' and the subsequent discussion of complex products in Turner, $\mathrm{n} 6$ above, 14 and 22, 28.

19 US Department of the Treasury, 'Financial Regulatory Reform. A New Foundation: Rebuilding Financial Supervision and Regulation' (undated) 47 at <http://www.treasury.gov/initiatives/wsr/ Documents/FinalReport_web.pdf $>$.

20 The playwright David Hare concluded in a recent work that ' $[n$ Tobody understood them. Even Alan Greenspan [...] he didn't understand them [...] He said he had hundreds of people with PhDs working for him and they didn't understand them either'. The Power of Yes: A Dramatist Seeks to Understand the Financial Crisis (London: Faber and Faber, 2009), 34.

${ }^{21}$ H. Davies, 'With the Benefit of Hindsight: Lessons from the Credit Crisis for Banks, Regulators and Central Banks' (Speech given in Singapore, 10 November 2008), 3 at <http://www2.lse.ac.uk/ aboutLSE/meetTheDirector/speechesAndLectures/home.aspx>.

22 C. Morris, The Trillion Dollar Meltdown: Easy Money, High Rollers and the Great Credit Crash (London: PublicAffairs Ltd, 2008), xvi.

23 ibid, 79.

${ }^{24}$ European Central Bank/Eurosystem, n 4 above, 30. See also the account of the aftermath of AIG's downgrading in Glass, $\mathrm{n} 5$ above, S88.

${ }^{25}$ European Central Bank/Eurosystem, ibid, 29.

26 ibid, 4.

27 European Central Bank/Eurosystem, n 12 above, fn 17, as well as European Central Bank/Eurosystem, n 4 above, 28 (describing AIG as 'too interconnected and too big to fail').

${ }^{28}$ European Central Bank/Eurosystem, n 4 above, 4-5. 
about extending CCP clearing as a way of increasing transparency and stability. As Glass put it, 'the current financial crisis has been a game-changer for the prospect of CCP clearing of credit derivatives'. ${ }^{29}$

\section{WORLDWIDE PROPOSALS TO EXTEND CCP CLEARING}

As the causes of the financial crisis were being studied by regulators around the world, a consensus quickly formed behind the proposal to extend CCP clearing to the CDS markets. Significantly, the leaders of the G20 made a commitment to this reform relatively early on. The document produced at their London Summit of April 2009 stated that 'We will promote the standardisation and resilience of credit derivatives markets, in particular through the establishment of central clearing counterparties subject to effective regulation and supervision. ${ }^{30}$ The G20 then followed up in September 2009 with a more detailed agreement. Notably, this document extended the types of OTC derivatives which were being targeted, stating that:

All standardized (sic) OTC derivatives contracts should be traded on exchanges or electronic trading platforms, where appropriate, and cleared through central counterparties by end-2012 at the latest. OTC derivatives contracts should be reported to trade repositories. Non-centrally cleared contracts should be subject to higher capital requirements. ${ }^{31}$

This September 2009 G20 proposal to require CCP clearing of all standardised products across the OTC derivatives markets has subsequently framed the international debate. The discussion below considers the position in the UK, the EU and the USA, but consultation about introducing similar regulation is also currently underway in other G20 markets such as China. ${ }^{32}$

In the UK, the FSA and HM Treasury have stated that that they 'strongly support' the extension of CCP clearing in the OTC derivatives markets. ${ }^{33}$ However, amongst other reservations, a joint December 2009 report expressed concern about the G20's proposal that '[a]ll standardized derivatives contracts' be cleared, arguing that there is more to being 'clearing eligible' than a contract simply

\footnotetext{
${ }^{29}$ Glass, n 5 above, S81.

${ }^{30}$ G20, 'Declaration on Strengthening the Financial System' (London, 2 April 2009) under the heading 'The Scope of Regulation' at <http://www.g20.utoronto.ca/2009/2009ifi.html>.

31 G20, 'Leaders' Statement: The Pittsburgh Summit' (Pittsburgh, 24-25 September 2009), [13] at $<$ http://www.pittsburghsummit.gov/mediacenter/129639.htm>.

32 The Hong Kong Securities and Futures Commission plans to 'consult the market on the regulatory regime [for the OTC derivatives markets] by the third quarter of 2011' on the basis that this is 'an important move for Hong Kong to keep pace with international initiatives on this front'. Regulatory Regime for the OTC Derivatives Markets (Press release, 10 December 2010) at <http://www.sfc.hk/ sfcPressRelease/EN/sfcOpenDocServlet?docno=10PR145>.

33 FSA and HM Treasury, Reforming OTC Derivative Markets: A UK Perspective (December 2009), 11 at $<$ http://www.fsa.gov.uk/pubs/other/reform_otc_derivatives.pdf $>$.
} 
being made on standardised terms. ${ }^{34}$ In particular, this report drew attention to the need for there to be sufficient market liquidity to support clearing services.

The Bank of England has also expressed its support for the CCP prescription, though in tightly drafted terms which referred to the expansion of the use of central counterparties for the clearing of vanilla over-the-counter (OTC) instruments'. ${ }^{35}$ On the basis of recent Financial Stability Reports, the Bank is particularly concerned about the risk management practices of CCPs themselves. ${ }^{36}$ Indeed, the Bank's December 2010 Report raised concerns about global standards for CCP risk management, ownership structures, and CCPs' collateral buffers. ${ }^{37}$ It even went so far as to suggest that CCPs that are 'not-for-profit [and] user-owned' may be in a position to manage risk more effectively than those run on a 'forprofit' model, and that 'governance reform of CCPs might be needed over time given their increasing systemic importance'. 38

At the EU level, extending CCP clearing for all classes of OTC derivatives has been embraced with enthusiasm. Extensive consultations recently culminated in a proposal for a Regulation on OTC derivatives, central counterparties, and trade repositories. ${ }^{39}$ This proposed Regulation mandates CCP clearing for 'all OTC derivatives which are considered eligible' and which are entered into between financial counterparties or between a non-financial counterparty and a financial counterparty in certain circumstances. ${ }^{40}$ The proposed Regulation also lays down detailed new rules for the regulation of CCPs themselves, ${ }^{41}$ and it requires all market participants to provide specified information about their OTC derivatives dealings to trade repositories or a competent authority. ${ }^{42}$

\footnotetext{
34 ibid.

35 Included in a list of areas where the 'Bank believes change is needed' in Bank of England, Financial Stability Report (June 2009), 36 at <http://www.bankofengland.co.uk/publications/fsr/2009/fsr25.htm>. 36 ibid, 54.

${ }^{37}$ Bank of England, Financial Stability Report (December 2010), 57 at <http://www.bankofengland.co.uk/ publications/news/2010/147.htm>.

$38 \mathrm{ibid}, 57$. This proposal has caused a certain amount of controversy, for example as discussed in N. Cohen and J. Grant, 'Clearers' Ownership Model Under Scrutiny' (22 December 2010) Financial Times.

39 Proposal for a Regulation on OTC Derivatives, Central Counterparties and Trade Repositories COM(2010) 484/5; 2010/0250 (COD) (Proposed Derivatives Regulation).

$40 \mathrm{ibid}$, Title II, art 3(1). Clearing will be required for contracts between a financial and non-financial counterparty unless the latter's transactions relate to its commercial activities or fall below a certain threshold, which is to be defined separately. Title II, arts 7(2) and (4).

$41 \mathrm{ibid}$, Titles III and IV. These proposed provisions should also be read alongside a more recent European Commission consultation paper which discusses the possible introduction of rules imposing a positive capital change for banks' exposures to CCPs. The paper proposes these charges should be lower if the CCP in question is a 'qualifying' CCP. A qualifying CCP is defined as one which has complied with the Committee on Payment and Settlement Systems (CPSS) and the Technical Committee of the International Organisation of Securities Commissions (IOSCO)'s Recommendations for CCPs, as well as meeting other criteria. As the consultation paper states, 'the main reason behind this differentiation is the desire to provide incentives to use "qualifying" CCPs, which are deemed to be safer'. European Commission, 'Consultation Document: Counterparty Credit Risk' (9 February 2011), 5 at $<$ http://ec.europa.eu/internal_market/bank/regcapital/index_en.htm>.

42 Proposed Derivatives Regulation, n 39 above, Title II, art 6(1) and Title II, art 7(1) (non-financial counterparties only have to report positions above a threshold, which will be fixed separately).
} 
However, the proposed Regulation leaves open some fundamentally important operational issues. For instance, rather than set out on the face of the Regulation which contracts are to be affected, the new European Securities and Markets Authority (ESMA) is to be responsible for compiling the list of 'classes of derivatives' 43 which are 'eligible for the clearing obligation', and a mechanism is provided for how the ESMA is to add new classes to this list. ${ }^{44}$

While the stated goal is that new EU rules should be 'in place and operational' by the end of 2012,45 sweeping financial reform regulation has already been passed in the US in the form of the Dodd-Frank Wall Street Reform and Consumer Protection Act of 2010.46 Amongst its many provisions, the Act provides for compulsory CCP clearing in the OTC derivatives markets. Title VII ('Wall Street Transparency and Accountability', hereafter 'Title VII') is the main source of new rules for the OTC derivatives markets, though there are several provisions elsewhere in the Act that will also have a significant impact on participants in these markets. ${ }^{47}$

A detailed review of the provisions of the Title VII is outside the scope of this paper. However, some of the main provisions as regards the OTC derivatives market are as follows: it will be unlawful to engage in a swap unless it is submitted for clearing if it 'is required to be cleared'; 48 all swaps, regardless of whether they are to be cleared or not, will be subject to reporting requirements; ${ }^{49}$ and parties which are 'Swap Dealers', 'Major Swap Participants', or 'Major Security-Swap Participants' entering into non-cleared swaps will have to meet capital requirements and post initial and variation margin. ${ }^{50}$

43 This term is defined as derivatives that 'share common, essential characteristics'. In a complex and innovative market, it is submitted that this may not prove to be a very practical definition. ibid, Title I, art 2(4).

44 ibid, Title II, art 4.

45 European Commission, 'Commission Proposal on OTC Derivatives and Market Infrastructures Frequently Asked Questions’ (MEMO/10/410, 15 September 2010).

46 H.R. 4173, signed into law by President Obama on 21 July 2010 (The Dodd-Frank Act). The scope of the Act is captured by its long title: 'An Act to promote the financial stability of the United States by improving accountability and transparency in the financial system, the end "too big to fail", to protect the American taxpayer by ending bailouts, to protect consumers from abusive financial services practices, and for other purposes'.

47 For example, the new limits on banks' proprietary activities in the Dodd-Frank Act, Title VI ('Improvements to Regulation of Bank and Saving Association Holding Companies and Depository Institutions').

48 As regards swaps: Dodd-Frank Act, s 723(a), inserting Commodity Exchange Act (7 U.S.C. 2), s 2(h)(1)(A). As regards security-based swaps: Dodd-Frank Act, s 763, inserting Securities Exchange Act of 1934 (15 U.S.C. 78 a et seq), s 3C(a)(1). (The Dodd-Frank Act, Title VII provides separately for two types of swaps: 'swaps' and 'security-based swaps'.

Swaps are regulated by the Commodity Futures Trading Commission (CFTC), and security-based swaps are the responsibility of the Securities and Exchange Commission (SEC). The definition of both terms is addressed within the Act. These definitions will not be explored further in this paper as the two sets of provisions in the Act largely mirror each other. However, for the sake of completeness, references to the Act are provided for both categories of swaps).

49 As regards swaps, Dodd-Frank Act, s 727, inserting Commodity Exchange Act (7 U.S.C. 2(a)), s 2(a)(13). As regards security-based swaps: Dodd-Frank Act, s 763, inserting Securities Exchange Act of 1934 (15 U.S.C. $78 \mathrm{~m})$, s $13(\mathrm{~m})$.

50 The meaning of which is explained in the text to note 97. As regards swaps: Dodd-Frank Act, s 731 inserting Commodity Exchange Act (7 U.S.C. 1 et seq.), s 4s(e)(2)(A) and (B). As regards security-based 
This Act is, in the words of one law firm, 'massive'.51 Title VII alone represents a major overhaul of US financial regulation, and when combined with provisions elsewhere in the Act, it will dramatically change the regulatory landscape of the OTC derivatives markets. However, as with much of the rest of the Act, definitions of fundamentally important terms, key details about how the provisions will actually work in practice, and secondary rules which are needed to flesh out the new regulatory framework have been reserved for the Securities and Exchange Commission (SEC) and Commodity Futures Trading Commission (CTFC) and other regulators. For that reason, the debate about how the CCP prescription should work in practice still has a long way to go, even in the US.

The story of the CCP prescription so far can therefore be characterised as one which started with high-level principles expressed by authorities keen to respond promptly to the weaknesses that the financial crisis revealed in the CDS market. Since then, it is possible to track the emergence of a broad, international consensus behind the increased use of CCP clearing across the OTC derivatives markets. However, as the debate has worn on, the sheer complexity of implementing new rules has caught up with legislators, triggering divergence and even disagreement on a number of technical issues that promise to be critical to the effectiveness of reform. As a result, fundamental details about how this reform will work in practice still remain open and, even with the Dodd-Frank Act now signed into law in the US, it remains true to say that no jurisdiction has yet set down clear rules on fundamental issues such as which products will and will not have to be cleared.

There are clearly multiple drivers behind this complexity, including the fact that the debates are proceeding across different national and transnational jurisdictions simultaneously. But while the challenges of international coordination have been widely acknowledged, ${ }^{52}$ there has been a less coherent approach within

swaps: Dodd-Frank Act, s 764, inserting Securities Exchange Act of 1934 (15 U.S.C. 78a et seq.), s $15 \mathrm{~F}(\mathrm{e})(2)(\mathrm{A})$ and $(\mathrm{B})$.

51 DLA Piper, 'Dodd-Frank Alert: Regulators Take Centre Stage' (2010) 1 at <http:// www.dlapiper.com/files/upload/dodd-frank-act.pdf $>$.

52 In particular, as regards the importance of a coordinated approach to standard-setting for CCPs. International coordination is being facilitated in this respect by the work of the CPSS and IOSCO, which are currently engaged in an ongoing review (at the G20's request) of their recommendations for CCPs.

The European Commission has also recently emphasised the need for global coordination in terms of these reforms, referencing the awaited review by CPSS and IOSCO and citing the OTC Derivatives Regulators' Forum which 'was established to promote cooperation between regulators'. n 45 above. The House of Lords European Union Committee (HL EU Committee) has welcomed what it sees as the Commission's 'acknowledgement of the need to develop a coordinated global approach in line with the work of CPSS and IOSCO'. House of Lords European Union Committee, The Future Regulation of Derivatives Markets; Is the EU on the Right Track? Report with Evidence, HL Paper 93 (10th Report of Session 2009-2010, 31 March 2010), 42 (HL EU Committee Report).

US legislation also acknowledges the need for international coordination. For example, the DoddFrank Act, s 722 addresses the extraterritorial application of the legislation while s 719(c) requires the CFTC and SEC within 18 months of the Act to jointly conduct a study into swap regulation, clearing house and clearing agency regulation in the US, Asia, and Europe identifying 'areas of regulation that could be harmonized'. 
the debates to an equally important source of complexity. This is the fact that the CCP prescription incorporates into legislation CCP clearing, a privately owned and operated risk management device that is a product of various private law techniques.

Of course, certain aspects of the private nature of CCPs have had an impact upon the public debates about the CCP prescription. Expert witnesses from clearing house companies, trade associations, end-users, and dealers gave detailed evidence to the House of Lords European Union Committee (HL EU Committee) about how their businesses work, making a considerable impact on the Committee's final report. ${ }^{53}$ The European Commission's consultations sought the views of hundreds of parties from the private as well as public sectors. ${ }^{54}$ Nonetheless, I argue below that the public debates would benefit from addressing the private nature of CCPs upfront and in a more coherent way, rather than dealing with the implications as part of a long list of other issues. To put it another way, the debates described in this part of the paper have tended to centre on the question of how this particular reform should work in practice, at the expense of considering in detail the legal nature of the CCP device that the public sector is seeking to incorporate into legislation. As discussed in the next part of the paper, the nature of CCP clearing can be usefully explored as a matter of private law, and the benefit of this approach is that it helps to systematise the various problems thrown up in the public debates about this reform thus far.

\section{A PRIVATE LAW PERSPECTIVE}

As Waddams notes, 'Anglo-American law has claimed many merits, but linguistic and conceptual precision are not among them'.55 However, in the financial markets literature, 'private law' typically refers to the legal norms used by private actors to 'create or alter private rights'56 as between themselves. This can be distinguished from the legal norms imposed on them 'from outside' by public actors such as legislators. Though the distinction between private and public actors may be a particularly artificial one in the context of what Black has described as the highly 'decentred' and 'hybrid' context of financial regulation, ${ }^{57}$ it is possible to be more precise when addressing a particular sector of the markets. For example, in Partnoy's critique of the role of 'private law' within the

\footnotetext{
53 See HL EU Committee Report, ibid, 46, Appendix 2 (List of Witnesses).

54 As explained in European Commission, 'Explanatory Memorandum to the Proposal for a Regulation on OTC Derivatives, Central Counterparties and Trade Repositories' (COM(2010) 484/5, 2010/0250(COD)), 3-4.

55 S. Waddams, Dimensions of Private Law: Categories and Concepts in Anglo-American Legal Reasoning (Cambridge: Cambridge University Press, 2003), 1.

56 Black's description of one of the function of legal norms. J. Black, Mapping the Contours of Contemporary Financial Services Regulation' (2002) 2 Journal of Corporate Law Studies 253, 256.

57 Black explores the 'hybridity' of decentred financial regulation by focusing on the 'extremely wide range of actors who are or potentially could be involved in the regulatory process'. ibid, 262.
} 
fragmented regulation of the derivatives market he discusses the use of the standard form contracts created by the International Swaps and Derivatives Association (ISDA) 58 and the effects on derivative counterparties' rights of the disclaimers therein. 59

Studies of private law in the financial markets are often preoccupied with the nature of the contracts, or even individual contractual terms, which market participants enter into with one another; hence the large literature about standard form contracts or boilerplate drafting in the sovereign debt, ${ }^{60}$ syndicated loan, ${ }^{61}$ and OTC derivatives markets. ${ }^{62}$ Valuable studies have highlighted how market actors use sophisticated standardised contracts and other drafting techniques to mitigate credit risk when they are relatively unprotected by public sector rules, ${ }^{63}$ to send a signal to public authorities and other non-parties, ${ }^{64}$ and otherwise to facilitate international transactions. ${ }^{65}$

But there is more to private law in the financial markets than the skilful use of contracts, and in practice parties often pursue their goals by deploying a number of legal techniques (such as asset-backing and netting) in combination with one another. For example, collateralisation in the OTC markets, as studied by Riles in her anthropological work on Japanese derivatives dealers, turns on the interaction of standardised contracts with the transfer of rights in property which together enable the parties to bypass national bankruptcy laws on the insolvency of a derivatives counterparty. ${ }^{66}$ Other examples of the deployment of interacting private law techniques are found in the use of special purpose vehicles in securitisation transactions (involving asset-backing, limited liability companies and trust structures), ${ }^{67}$ close-out netting as used in master agreements (standardised contracts, novation $)^{68}$ and, most importantly for these purposes, central

\footnotetext{
58 ISDA is the trade association for participants in the privately negotiated derivatives markets. See $<$ http://www.isda.org/>. F. Partnoy, 'The Shifting Contours of Global Derivatives Regulation' (2001) 22 University of Pennsylvania Journal of International Economic Law 421, 479.

59 ibid, 478-481.

${ }^{60}$ For example, A. Gelpern and M. Gulati, 'Public Symbol in Private Contract: A Case Study' (2006) 84 Washington University Law Review 1627; C. Bradley, 'Private International Law-Making for the Financial Markets' (2005) 29 Fordham International Law Journal 127, 160-164; and the first case study in S. Choi and G. Mitu Gulati, 'Contract as Statute' (2005-2006) 104 Michigan Law Review 1129, 1133-1139.

${ }^{61}$ For example, Bradley, ibid, 166-170; Benjamin, n 8 above, 157-170.

${ }^{62}$ For example, Partnoy, n 58 above; Murray, n 9 above; A. Riles, 'The Anti-Network: Private Global Governance, Legal Knowledge, and the Legitimacy of the State' (2008) 56 American Journal of Comparative Law 605; J. Golden, 'The Future of Financial Regulation: The Role of the Courts' in I. MacNeil and J. O'Brien (eds), The Future of Financial Regulation (Oxford and Portland, Oregon: Hart, 2010), discussing the implications of post-crisis litigation for markets which use standardised contracts, making particular reference to the ISDA documentation; and Choi and Gulati, n 60 above, 1139-1144.

${ }^{63}$ Benjamin, $\mathrm{n} 8$ above, 233-240 and 256-257.

${ }^{64}$ Gelpern and Gulati, n 60 above, 1712-1714.

${ }^{65}$ Riles, $\mathrm{n} 62$ above.

66 ibid 610-612.

${ }^{67}$ As discussed in D. McBarnet, 'Financial Engineering or Legal Engineering? Legal Work, Legal Integrity and the Banking Crisis' in MacNeil and O'Brien (eds), n 62 above, 70-72.

68 Murray, n 9 above, 291-293. See also the discussion of close-out netting in the context of the repo markets in Benjamin, $\mathrm{n} 8$ above, 320-321.
} 
counterparty clearing. I collectively refer to these market-generated products of various private law techniques as 'legal devices'.

Though these legal devices are diverse, certain themes cut across the class. For example, the extent to which they are supported by legislation is striking. This support may be provide in one or both of two ways: through facilitative legislation (for example, as seen in the EU Financial Collateral Directive (FCD)'s provisions facilitating the posting of collateral by way of a title transfer collateral arrangement or security) ${ }^{69}$; and by legislation which disapplies 'unhelpful' rules (for example, the FCD's disapplication of certain registration and insolvency rules for transactions within its ambit, ${ }^{70}$ and the US Bankruptcy Code's 'safe harbor' provisions protecting certain types of derivatives contracts from the operation of bankruptcy law). ${ }^{71}$

A second theme present within this class of legal devices relates to their capacity, understood for these purposes as a function of the underlying legal techniques. On this basis, the legal techniques underpinning these devices merit detailed attention in their own right because they determine a device's inherent features, including their benefits, limitations, and weak spots. This insight is especially useful when, as in the case of CCP clearing, a device is to be incorporated into financial regulation by the public sector with the intention that it perform various, critical regulatory functions.

The operation of CCP clearing can therefore be understood as depending on the interaction of a number of different legal techniques, which in turn define its capacity. The most important of these are considered below, along with the implications for the ongoing debate about CCP prescription. The specific focus in the following discussion is on English law, though of course the worldwide reforms discussed in the preceding part of the paper above will implicate CCPs in many different countries. However, it is submitted that the analytical approach developed here is applicable to CCPs generally, regardless of governing law.

\section{NOVATION AND STANDARDISATION}

Perhaps the most fundamental legal point about CCP clearing is that the contracts in question are between the ССP and the members of the clearing system rather than between members themselves. This arrangement lies at the heart of the operation of CCP clearing, and it is reflected in the European Central Bank's definition of a 'central counterparty' as 'an entity that interposes itself, in one or

\footnotetext{
${ }^{69}$ Such provisions include Financial Collateral Directive 2002/47/EC, art 5, which protects the collateral taker's exercise of a right of use over the collateral it receives from the collateral giver.

${ }^{70}$ Financial Collateral Directive 2002/47/EC, arts 3 and 8 respectively.

7111 U.S.C. $\int 560$. These safe harbour provisions protect a non-defaulting swap counterparty's contractual rights to liquidate, terminate, or accelerate one or more swap agreements because of the insolvency of the counterparty and 'offset or net out' sums so due. In a recent case related to the Lehman Brothers administration, safe harbor provisions were (unsuccessfully) raised in an attempt to save certain contractual provisions from the operation of bankruptcy law. Lehman Brothers Special Financing Inc v BNY Corporate Trustee Services Ltd, Proceeding no. 09-01242 (Bankr. SDNY January 25 2010), 21-22.
} 
more markets, between the counterparties to the contracts traded, becoming the buyer to every seller and the seller to every buyer and thereby guaranteeing the performance of open contracts. ${ }^{.} 2$

Depending on the structure of the clearing system in question, this outcome may be achieved either by members A and B contracting in the first instance with the CCP, or by A and B contracting with each other initially, after which their contract is replaced by new ones between each member and the CCP. ${ }^{73}$ This latter arrangement depends on the legal technique of novation, which cancels one contract and replaces it with another. Novation is notable as the only means in English law whereby the benefits and burdens of a contract may effectively be transferred to a third party. ${ }^{74}$ Its capacity to bring about this 'clean break' allows the bilateral contract between $\mathrm{A}$ and $\mathrm{B}$ to be replaced by parallel contracts between $\mathrm{A}$ and the CCP and $\mathrm{B}$ and the CCP, with no rights and obligations (and therefore no counterparty risk) remaining between the original parties.

That the CCP becomes the 'buyer to every seller and the seller to every buyer' underpins some of the most important benefits of the CCP prescription. As discussed further below, it means that the CCP can act as a shock absorber on the insolvency of a market participant. It also means that the CCP will be in a position to collect critical information about the market. As explained above, the opacity of the CDS market to date has become a particular cause of concern for regulators. As the FSA and HM Treasury have stated in this context: 'More generally, imperfect market information also limits a regulator's ability to monitor systemic risks and act to mitigate them, and weak trade transparency for OTC contracts can negatively affect price efficiency. ${ }^{75}$ In order to capitalise on this informationgathering function, the Dodd-Frank Act expressly provides for CCPs (as well as trade repositories and other market participants) to be required to furnish information to regulators to help them detect and deter market abuses. ${ }^{76}$

To facilitate a CCP acting as buyer to every seller and vice versa (whether through novation or otherwise) the contracts being cleared would normally be in a standardised form. In terms of the underlying legal techniques, this can be understood as contractual standardisation coming together with novation to facilitate the process of clearing.

\footnotetext{
72 European Central Bank/Eurosystem, 'Glossary of Terms Related to Payment, Clearing and Settlement Systems' (December 2009), 4.

73 See the detailed discussion of how these alternatives work in different clearing systems provided by LCH in M. Yates, 'UK Settlement' in Blair and Walker (eds), n 2 above, 321-324.

${ }^{74}$ For a discussion of the different ways in which the transfer of assets may be effected under English law, including by means of novation, see Benjamin, $\mathrm{n} 8$ above, 528-531.

${ }^{75}$ FSA and HM Treasury, $\mathrm{n} 33$ above, 6.

${ }^{76}$ For example, as provided for in the Dodd-Frank Act, s 725(c) inserting Commodity Exchange Act (7 U.S.C. $7 \mathrm{a}-1(\mathrm{c}))$, s $5 \mathrm{~b}(\mathrm{c})(2)(\mathrm{K})$ and $(\mathrm{L})$, which addresses the recordkeeping and disclosure obligations of clearing houses. This section provides that certain information is to be made public and disclosed to the CFTC, including the terms and conditions of each contract cleared, margin-setting methodology, and daily settlement prices and volume.
} 
The debate about the CCP prescription in the OTC derivatives market has tended to proceed on the basis of three assumptions about contractual standardisation: that greater standardisation is a good thing; that only standardised OTC derivatives products can be cleared; and that all standardised products should be forced into a clearing system. However, a closer look at what is involved in CCP clearing and at the legal technique of contractual standardisation shows that qualifications should be made to each of these assumptions.

First, the assumption that greater contractual standardisation in the OTC markets is a good thing: Across the debates since the crisis broke, there has been widespread approval of increasing the use of standardised OTC derivatives documentation. As the FSA and HM Treasury have noted approvingly, ISDA is currently leading industry efforts to increase standardisation in particular OTC derivatives markets including CDS. ${ }^{77}$ Robert Pickel, the CEO of ISDA has observed that the 'natural evolution of successful derivative products is in the direction of greater standardisation',78 and (writing before the crisis) Walker also described standardisation in the OTC markets as a 'useful device'. ${ }^{79}$

However, the implications of the wider use of standardised contracts deserve to be discussed more thoroughly as part of the debate about extending CCP clearing. As a practical point, the law firm Ashurst LLP raises the point that the meaning of 'standardised' will be uncertain in practice, which may result in participants seeking legal opinions that their particular 'contractual arrangement' qualifies and should therefore be cleared by a CCP, potentially passing on 'unmanageable risk'. ${ }^{0}$ This raises the possibility of regulatory arbitrage by parties trying to get their contract cleared (rather than seeking to circumvent clearing requirements, which is the usual worry in these debates). Moreover, if the public sector mandates or otherwise works to increase the use of standardised documentation, this will have a knock-on effect on the regulatory role played by the trade associations or other actors responsible for producing it. Indeed, some academics have already expressed concern about the processes behind standard form documentation in the financial markets. For example, looking from the perspective of transparency and the processes of law-making, Bradley has expressed concern that standard form contracts 'can constrain or limit regulation' and that the 'processes which produce [them] are private and opaque to outsiders' ${ }^{81}$

The contract law literature also helps to shed light on the use and properties of standardised contracts in the financial markets, ${ }^{82}$ and it provides a useful insight

\footnotetext{
${ }^{77}$ FSA and HM Treasury, n 33 above, 9.

78 R. Pickel, 'Navigating the Financial Crisis: Choosing the Right Path for the Derivatives Industry' (2009) 4(S1) Capital Markets Law Journal S72.

${ }^{79}$ G. Walker, 'Financial Markets and Exchanges' in Blair and Walker (eds), n 2 above, 61.

80 Memorandum by Ashurst LLP providing evidence to the HL EU Committee, in the HL EU Committee Report, n 52 above, 55.

81 Bradley, n 60 above, 174.

82 See also the work of Riles, who explores in some detail how standard contracts are used in practice, for example, contrasting the socio-legal view that they represent the production of new legal regimes
} 
into the potential implications of increasing standardisation in this case. In particular, Collins has shown how contractual standardisation is a powerful tool which allows autonomous 'club markets' to transform 'contracts into things' 83 (or 'objects of property' ${ }^{84}$, thereby making possible a trade in futures contracts. However, he also shows how this use of standardised contracts necessarily excludes the 'unusually reflexive' qualities of contract law 'as a regulatory mechanism'. ${ }^{85}$ This means, for example, that parties may not negotiate to resolve disputes on their own terms. In other words, market participants necessarily sacrifice a wealth of rights afforded by the private law system in return for the benefits of participating in autonomous, organised markets. ${ }^{86}$ In the context of the OTC derivatives markets, some of those rights (for example, which allow parties to hedge specific risks, tailoring their contracts by reference to the nature and dates of exposure they are facing) may well be very important for certain participants. There has been some discussion relating to these issues in the debate about the CCP prescription so far; for example, it has been argued that the CCP prescription represents 'further specific restrictions on derivative transactions' and impacts upon parties' freedom of contract. ${ }^{87}$ However, the principal focus to date has been those parties who will continue to require bespoke products (as discussed, for example, by HM Treasury in its evidence to the HL EU Committee) $)^{88}$ rather than the constraints that standardised contracts impose on parties using them .

The second assumption commonly made in the debate about the CCP prescription is that only standardised contracts can be cleared. For example, the European Central Bank/Eurosystem has stated that 'to be eligible for clearing a product must, as a minimum, be liquid, have price transparency and be standardised'. ${ }^{99}$ However, evidence put to the HL EU Committee by LCH made it clear that certain non-standardised contracts could be accepted for clearing by a clearing house, as is the case with its portfolio of swaps..$^{90}$ Thus, standardisation is not an essential prerequisite for CCP clearing. Using standardisation as a

through the routinization of work and professional roles' with the law and economics perspective that they represent 'costs savings'. Riles, n 62 above, 624 .

${ }^{83}$ H. Collins, Regulating Contracts (Oxford: OUP, 1999), 209-222.

${ }^{84} \mathrm{H}$. Collins, 'Regulating Contract Law' in C. Parker, et al (eds), Regulating Law (Oxford: OUP, 2004), 25.

$85 \mathrm{ibid}, 24$, discussing Collins, $\mathrm{n} 83$ above, 65-69.

86 ibid, 26.

87 Ashurst LLP, n 80 above, 52.

88 Non-financial firms, in particular, have a legitimate need to transfer their risks using bespoke products'. Supplementary letter from HM Treasury, HL EU Committee Report, n 52 above, 17. For example, airlines use derivatives to address the risk associated with fluctuating aviation fuel prices. See the Memorandum by British Airways, providing evidence to the HL EU Committee, at HL EU Committee Report, n 52 above, 68-71.

${ }^{89}$ European Central Bank/Eurosystem, n 4 above, 79.

${ }^{90}$ Transcript, Examination of Witnesses R. Liddell (Chief Executive, LCH) and R. Cunningham (Director of Public Affairs, LCH), HL EU Committee Report, n 52 above, 46-47, Q126. (In evidence, Mr Liddell stated that it is 'easier' to clear contracts if they are standardised, but non-standardised contracts could be accepted for clearing, too. He gave as an example LCH's swap portfolio, which he described as 'simple and vanilla in its risk but not standardised in terms of transactions'.) 
shorthand to describe which contracts can or should be cleared is therefore an oversimplification; rather, standardisation is better understood as one of several factors affecting the decision of private clearing houses about the sorts of risks they are willing and able to manage..$^{11}$

The third common assumption is that the CCP prescription should involve forcing all standardised products onto clearing. This goes back to the G20's statement that '[a]ll standardized OTC derivatives' should be cleared, which has been endorsed by the European Commission. However, considering this proposition from the point of view of CCP clearing systems shows that if this proposal were taken literally, it could have an adverse effect on the stability and risk management of clearing houses. As the report of the HL EU Committee put it, 'CCPs are privately owned companies, which can currently refuse to clear products where they feel they cannot manage the associated risk and this system has worked well even during the financial crisis. ${ }^{92}$ Being able to select which products to clear goes to the heart of the risk management practised by CCPs, and this might mean that some standardised contracts are not in fact clearable. If legislation were to force CCPs to clear, for example, illiquid but standardised products, this could adversely affect their ability to manage their own risk. In short, CCP clearing systems could become more vulnerable if their own decisions about which contracts to clear were overridden by public sector rules. Weakening the resilience of CCPs would, of course, be disastrous and ultimately risk defeating the whole object of this legislative exercise.

Thus, the legal technique of standardisation is central to the debate about the CCP prescription because of how CCP clearing works as a matter of law. However, certain assumptions by policymakers have oversimplified the relationship between clearing eligibility and standardisation. An overly blunt legislative definition of those products which must be cleared could threaten the autonomy of CCPs to choose what to accept for clearing. While it will be a significant weakening of the original goal to clear all standardised contracts, the legislative definition of the products that must be cleared must provide (as US legislation does) for the CCPs to retain control of which products they clear. Overall, a more nuanced approach to 'clearing eligibility' than has been shown by some authorities to date is going to be necessary for CCPs to work safely and effectively within a new legislative framework.

${ }^{91} \mathrm{LCH}$ has stated that 'the fundamental requirement for eligibility is that the CCP can manage the default of a participant through the implementation of both its risk management and default management policies in a way that controls systemic risk'. It explained that there are four main considerations for the clearing house in this regard, which can be summarised as: the assurance of market liquidity; availability and reliability of market prices; CCP default management procedures; and cost of providing clearing service and maintaining risk management structures. Memorandum by LCH providing evidence to the HL EU Committee, at HL EU Committee Report, n 52 above, 41.

The Future and Options Association (FOA) gave the following as examples of factors affecting clearing eligibility: 'pricing transparency, liquidity, volatility, risk complexity, valuation capability and the risk management capacity of the CCP'. Memorandum by the FOA, providing evidence to the HL EU Committee, at HL EU Committee Report, n 52 above, 90.

${ }^{92}$ HL EU Committee Report, n 52 above, 31-32. 


\section{FINANCIAL COLLATERAL AND ASSET-BACKING}

Benjamin describes the provision of financial collateral as 'the use of financial assets in security, quasi-security or title transfer collateral arrangements'. ${ }^{93}$ In turn, she collectively describes these legal techniques as asset-backing, whereby 'the credit exposure of the position taker is addressed by earmarking particular assets to meet its claims..$^{94}$ Asset-backing is an important feature of CCP clearing as members are required to post financial collateral as margin to cover their exposures to the CCP. As discussed above, the novation of members' contracts to the CCP means that if one member were to default, the CCP would still owe the corresponding obligations to other members. Thus, this collateral is a vital first (but not only) ${ }^{95}$ line of defence for the CCP in the case of the failure of a market participant. LCH, for example, reported to the HL EU Committee that it held 'initial margin' (explained below) totalling $£ 50$ billion. Moreover, it reported that its holding of $\$ 2$ billion (sic) of initial margin in respect of Lehman Brothers easily absorbed the outstanding obligations owed to counterparties on the bank's default in 2008.96

Looking at the legal nature of members' asset-backing obligations more precisely, members are required to post collateral as transactions are registered (initial margin) and then from time to time as provided for by the clearing house rules (variation margin). ${ }^{97}$ Yates notes that under the LCH Rules, initial margin may be provided in the form of various assets identified in LCH's General Regulations, but variation margin must be provided in the form of cash. ${ }^{98}$ The significance of posting collateral in cash is not only, as Benjamin notes, that it is the most sought after form of financial collateral and therefore highly in demand, ${ }^{99}$ but also that upon its transfer to the collateral taker (the CCP), the collateral provider becomes a creditor of the CCP. ${ }^{100}$ Moreover, the CCP's enforcement of rights against the cash collateral will be by way of set off, as between the credit balance of the member's account (the debt the CCP owes to the member) and the member's liabilities (its debt to the CCP). ${ }^{101}$

\footnotetext{
${ }^{93}$ Benjamin, $n 8$ above, 445.

94 ibid, 331.

95 Other resources which could be deployed in the event of a member's insolvency include the CCP's default fund and the capital resources of the CCP itself, as discussed in HL EU Committee Report, n 52 above, 29.

${ }^{97}$ For a further discussion of 'initial margin' and 'variation margins', see P. Wood, English and International Set-Off (London: Sweet \& Maxwell, 1989), 171 (noting that variation margins may be calculated daily or with greater frequency). The Turner Review found that the obligation in AIG's derivative contracts to post variation collateral as its credit worthiness fell contributed to the group's 'downward spiral' in September 2008. Turner, n 6 above, 22.

98 Yates, $\mathrm{n} 73$ above, 325.

${ }^{99}$ Benjamin, $\mathrm{n} 8$ above, 450 .

100 Yates, $\mathrm{n} 73$ above, 325. The implications of this point in the context of global custody are discussed in J. Benjamin and M. Yates, The Law of Global Custody (London: Butterworths LexisNexis, 2002), 25.

101 Yates, n 73 above, 325.
} 
In contrast, when members post collateral in the form of non-cash assets, the member may retain property rights in the collateral. In the LCH context, for example, Yates describes how members provide collateral in the form of non-cash assets (eg, securities) by transferring the assets to an account with LCH and granting LCH a security interest, ie LCH takes a first fixed charge to secure the member's performance of its obligations. ${ }^{102}$ This arrangement means that the member retains property rights in the asset which are, by definition, enforceable against third parties and survive the collateral-taker's insolvency. ${ }^{103}$ There is a clear contrast between the position of the member in this case and the position if it has provided cash collateral, where the member would merely have personal rights as an unsecured creditor of the CCP.

The legal effects flowing from the use of various types of financial collateral and asset-backing techniques may not, traditionally, have been at the forefront of market participants' minds. However, the insolvency of Lehman Brothers International (Europe) (LBIE), an important prime broker holding the assets of many hundreds of counterparties, ${ }^{104}$ has recently brought home the enormous implications of such legal details, albeit in a different context within the markets. In the immediate aftermath of LBIE's collapse, certain funds whose securities were held by LBIE applied for a court order which would have required the LBIE's administrators to provide them with information about the whereabouts of their assets. The applicants argued that the lack of information and delay in the return of their securities (while administrators tried to untangle the complex arrangements used by LBIE and other members of the Lehman Brothers group to hold and use client assets) was having a highly damaging effect on their business. However, the court ultimately rejected the application on the basis that the funds were not entitled to special treatment outside the normal workings of the administration process. ${ }^{105}$ The extension of CCPs to vast new areas of the market will therefore mean that the complex legal details which can arise in relation to asset-backing and the holding of one party's collateral by another will become even more significant within the financial system.

\footnotetext{
102 ibid.

${ }^{103}$ See the detailed discussion of the law of property in the context of the financial markets in Benjamin, n 8 above, ch 16.

The distinction between a prime broker's legal interest in clients' securities and cash was the backdrop to a recent case about the legal status of securities which had 'leaked' into cash immediately before the prime broker's insolvency. See In the Matter of Lebman Brothers International Europe (in administration), Anthony Victor Lomas and ors $\mathrm{v}$ RAB Market Cycles (Master Fund Limited) and anr [2009] EWHC 2545 (Ch).

104 As noted in a 2009 Court of Appeal decision, the administrators of Lehman Brothers International Europe wrote to 1,707 account holders who were 'thought to have potential claims against LBIE for the return of trust property'. In the Matter of Lehman Brothers International (Europe) (in administration) [2009] EWCA (Civ) 1161 at [8].

105 In the Matter of Lehman Brothers International (Europe) (in administration) [2008] EWHC 2869 (Ch). This judgment cites the (anonymised) applicants' evidence that if the present situation continues for very much longer the funds are virtually certain to lose the confidence of their investors so that they will suffer revenue impairment [...] In summary, the funds will suffer economic loss, and so will their investors unless their positions are transferred soon.' at [13].
} 
Moreover, the asset-backing requirements of CCPs may have an adverse economic effect on 'thinly capitalised' market participants, and private finance initiative (PFI) and public-private partnership (PPP) project companies are cited in this context by the FSA and HM Treasury. ${ }^{106}$ So, on top of the legal risks which collateralisation represents, the extended use of CCP clearing will also mean more pressure on good quality financial collateral and the possibility of some parties having to borrow to meet these requirements.

\section{NETTING: NON-INSOLVENCY}

CCP clearing allows members' positions to be netted in the ordinary course of events, ie when no members are insolvent. One benefit of this is that gross sums due between parties are replaced by a single net sum (owed to or by the CCP). This reduces parties' exposures and takes the pressure off the settlement infrastructure. The importance of this latter, operational point should not be underestimated. As Wood notes, in the late 1960s and early 1970s 'several major United States brokerage firms failed primarily because of their inability to process transactions. If buys and sells and corresponding payments can be netted, millions can be reduced to thousands.' ${ }^{107}$

It is the case that, outside insolvency, parties could achieve similar effects without the use of a CCP through careful contractual drafting. For example, parties may provide for multilateral netting, where all of the rights and obligations between multiple parties are replaced by a single sum owed to or by each party. Wood describes this as the 'non-mutual set-off of claims', noting that the objective is 'to minimise the number of actual transfers and circuity of contracts'. ${ }^{108}$ This contractual multilateral netting may be supported by a clearing house, though in this case its function would simply be to calculate the single sums owed to or by each party at the end of the payment cycle. In British Eagle International Airlines Ltd v Compagnie Nationale Air France, ${ }^{109}$ this sort of contractual multilateral netting was deployed by member airlines which owed money to and were owed money by each other because, for operational convenience, they sold tickets for services to be provided by other airlines. Facilitated by a clearing house, the International Air Transport Association (IATA), the arrangements brought considerable operational advantages: in one year, only nine per cent of gross sums owing between the members actually fell to be paid. ${ }^{110}$

If netting may be effected by the terms of the contracts between parties, why is CCP clearing useful? In addition to the operational advantages mentioned already, the main reason is that multilateral netting arrangements provided for in

106 FSA and HM Treasury, n 33 above, 13-14.

107 Wood, n 97 above, 170.

108 ibid, 185.

109 [1975] 2 All ER 390.

$110 \mathrm{ibid}, 404$, per Lord Cross. 
contracts will not survive the insolvency of one of the participants, as was famously held in British Eagle. In other words, as Wood says of such contractbased multilateral netting arrangements 'there is no objection to this as long as all parties are solvent'. ${ }^{111}$ Novating to the CCP overcomes this problem.

\section{NETTING: INSOLVENCY OF A CCP MEMBER}

One of the principal attractions of the CCP clearing is the capacity of the device to minimise market disruption on the insolvency of a market participant. For instance, evidence given to the HL EU Committee described how, on the administration of Lehman Brothers, the clearing house LCH was able to liquidate the portfolio and settle outstanding obligations to counterparties [...] [allowing] Lehman Brothers to default without significant adverse effects on its counterparties'. 112

But how, as a matter of law, does a CCP provide this effect? The House of Lords in the British Eagle case made clear that the CCP's capacity to handle the insolvency of a member turns on the process of novation; it also showed what happens to multilateral clearing arrangements on the insolvency of a member in the absence of a CCP.

In British Eagle, contractual provisions effected multilateral netting of rights and obligations between member airlines. However, when one member went into liquidation, the contractual provisions for multilateral netting were held to be ineffective in the face of the contrary provisions of the insolvency rules, which required bilateral netting. ${ }^{113}$ As Lord Cross explained in the leading speech on behalf of the majority, "[s]uch a "contracting out" must, to my mind, be contrary to public policy'.114 Thus, in the absence of novation to a CCP, the liquidators of the bankrupt airline were left able to pursue the debtors of the airline for sums owing to it, while its creditors had separately to prove their claims.

In the more recent High Court of Australia case of Ansett, ${ }^{115}$ the majority found the amended version of the IATA clearing scheme to be effective, notwithstanding the administration of a participant. Significantly, the drafting of the new scheme did not in fact effect novation. However, IATA submitted and the majority agreed that:

\footnotetext{
111 Wood, n 97 above, 186.

112 HL EU Committee Report, n 52 above, 29.

113 At the time, Companies Act 1948, s 302.

114 British Eagle, n 109 above, 411 per Lord Cross.

115 International Air Transport Association v Ansett Australia Holdings Ltd [2008] HCA 3 (6 February 2008).
} 
[...] under the Clearing House arrangements no liability to effect payment arises between airlines and that the only debt or credit which arises is that between IATA and the member airline in relation to the final, single balance of all items entered for the relevant clearance. This is the consequence of the bargain struck by airlines such as Ansett when they became parties to the relevant multilateral agreements. That construction of the Clearing House arrangements should be accepted. ${ }^{116}$

This case has important implications for the drafting of clearing house rules, though it is submitted that it does not disrupt the central point that novation to a CCP remains the safest and most conventional way of achieving the shock absorber effect on a member's insolvency. It is also worth noting that Ansett has attracted academic criticism for being 'generous to the architects of the scheme and somewhat unconvincing in its conclusions'. ${ }^{117}$

In practice then, novation to the CCP means that upon settlement each member of the clearing system owes a net sum of money to or is owed a net sum by the ССР. The members will have to post collateral accordingly. On the default of a member, other members' obligations to pay and be paid stand. The collateral taken by the CCP can be used to meet the CCP's losses because of the default, though, as ISDA explained in evidence to the HL EU Committee, in the first instance the CCP may look to other clearing members to assume the contracts which the defaulting member had on its books. ${ }^{118}$ Thus, through a combination of novation, netting, and collateralisation CCP clearing protects the markets from disruption on the default of a participant.

However, as Benjamin points out, 'financial law cannot reduce risk, but only moves it from person to person'. ${ }^{119}$ In the context of CCPs, this reminds us that while members are protected from direct exposure to counterparty insolvency risk, this risk is assumed by the CCP itself. Therefore the CCP prescription depends, as the Turner Review put it, on 'robust and resilient central clearing house arrangements for CDS clearing. ${ }^{120}$ This explains why it is so important that any rules about which contracts are to be cleared do not undermine risk management by clearing houses (as noted above). It also explains why the debate about the regulation and supervision of CCPs, already an important ongoing issue at an international level, has become intertwined with that surrounding the CCP prescription. ${ }^{121}$

116 ibid at [60] per Gummow, Hayne, Heydon, Crennan, and Kiefel JJ. Later the majority reiterated that 'no liability to effect payment arises between airlines'. ibid at [94].

${ }_{117}$ M. Bridge, 'Clearing Houses and Insolvency' (September 2008) 2 Law and Financial Markets Review 418, 420.

${ }_{118}$ Supplementary Memorandum by ISDA, HL EU Committee Report, n 52 above, 36.

119 Benjamin, $\mathrm{n} 8$ above, 266.

120 Turner, $\mathrm{n} 6$ above, 82 .

121 As the FSA and HM Treasury note in their recent joint publication about CCPs in the OTC derivatives markets, extending their use 'will further significantly increase the systemic importance of 


\section{MEMBERS’ CONTRACTUAL RELATIONS}

The final private law component of CCP clearing discussed here is the contractual relationship between the clearing house and the users of its services. This is sometimes overlooked in discussions of CCP clearing and has not received much attention in the debate about the CCP prescription so far. However, it is important in practice as it means that the CCP prescription has the potential to introduce another layer of complexity into the markets.

Parties contracting with a CCP in the manner described must be members of the clearing house. The relationship between the CCP and its members is governed by a membership agreement.122 Crucially, in light of the CCP's assumption of the insolvency risk of participants, there are criteria which parties have to meet before they are accepted as members of the clearing system. In LCH's case, it requires (amongst other criteria) that members have 'minimum levels of net capital', 'staff 'of sufficient knowledge and expertise of the products being cleared', and 'appropriate systems to cope with their clearing activities'. ${ }^{123}$ Yates observes that parties may either be individual clearing members (able to clear their own trades only) or general clearing members (able to clear their own trades and also those of customers who are not members themselves).124 However, members contract with the CCP as principals, even when they are entering into transactions for a client. ${ }^{125}$ Needless to say, the law may become quite complex in this area, for example as to whether the non-member is bound by rules and customs of the market (here the clearing service) of which he is ignorant. ${ }^{126}$ Yates explains that in the case of $\mathrm{LCH}$, where a member is acting as the agent for a non-member using the clearing services, the member must clear the contract through another general clearing member because otherwise it would be in the position of providing a service to its customer as agent and principal. ${ }^{127}$ General clearing members are also required to maintain separate accounts with $\mathrm{LCH}$ in respect of house (its own) transactions and client transactions. This separation is extremely important for purposes such as collateralisation.

There has been some concern expressed about how these arrangements will work in the context of the CCP prescription. For example, a recent European Central Bank/Eurosystem report flagged up what it called the 'non-trivial legal issues that will need to be addressed' before arrangements allowing non-dealers trading with clearing members to enjoy the benefits of CCP clearing will become

CCPs' thereby heightening the importance of rules imposed on CCPs about their 'capital, risk management, margining and operational standards'. FSA and HM Treasury, n 33 above, 14.

122 Typical obligations therein are discussed in Yates, $\mathrm{n} 73$ above, 320.

123 See the list of the 'minimum acceptance criteria' for membership of LCH, set out on the LCH.Clearnet Group's website at <http://www.lchclearnet.com/membership/ltd/default.asp > also discussing the costs of membership.

124 Yates, $\mathrm{n} 73$ above, 318.

125 ibid; R. Goode, Commercial Law (London: Penguin, 3rd ed, 2004), 158.

126 See Goode, ibid, 159, citing Robinson v Mollett (1875) LR 7 HL 802.

127 Yates, $\mathrm{n} 73$ above, 318. 
widespread. ${ }^{128}$ The FSA and HM Treasury have also expressed concern that legal arrangements allowing non-members access to clearing are sufficiently robust, and regulators are apparently monitoring progress in this respect. ${ }^{129}$

The framers of legislation mandating CCP clearing therefore need to fully consider the problems arising from the capacity of different sorts of market participants to access clearing services. Not all parties which currently enter contracts caught by new legislation will be willing or able to meet the criteria to be clearing members themselves, and the corporate end-users of derivatives hedging business risk again come to mind. Moreover, to the extent that such parties rely on members of the clearing service, there is potential for considerable legal complexity to result from the nature of arrangements which they make. This would be an unwelcome by-product of reform. On this basis it would seem sensible either to streamline the means of accessing clearing services for nonfinancial entities entering relatively low values of deals for the purposes of commercial hedging (perhaps by means of a publicly owned clearing house for non-financial entities only, with lower entry criteria and a maximum limit on participations) or, as the proposed EU Regulation does in some circumstances, to exempt these users entirely from mandatory clearing requirements.

To sum up, this analysis shows how the legal techniques underpinning CCP clearing help to define the capacity of this device. As shown, CCP clearing means that settlement volumes are reduced, netting is facilitated, counterparty risk is removed, and the markets are insulated should a participant fail. However, the underlying legal techniques mean that there are limitations built into CCP clearing, too. Most importantly perhaps, because of how novation works, risk will concentrate in the CCP itself, its own robustness thereby becoming an issue of systemic importance as more and more products are cleared. As a private entity, the clearing house's own management of risk remains crucial, including judging for itself which types of product can be cleared safely. Furthermore, a private law analysis also shows how complexity, legal risk, and cost can arise as by-products of contractual relations between members, non-members and the CCP, of the increased use of standardised products, and of the all-important (as Lehman Brothers showed) asset-backing requirements.

\section{IMPLICATIONS}

As I have argued, CCP clearing may usefully be understood as a private sector legal device, though this aspect of CCP clearing has not been addressed in a coherent way in the debates about the CCP prescription so far. It follows that

\footnotetext{
128 European Central Bank/Eurosystem, n 4 above, 52.

129 FSA and HM Treasury, n 33 above, 13.
} 
taking stock of how CCP clearing works offers a means with which to reconsider the complex debate surrounding the CCP prescription, including that following on from framework legislation such as the Dodd-Frank Act. More specifically, this approach assists by isolating two different types of challenges presented by the process of debating and implementing this reform.

In the first place, the analysis above has highlighted certain drawbacks associated with CCP clearing, such as the build-up of risk within the CCP itself. Because these risks, limits, and other potential problems originate in the legal workings of the device, they are an inherent and unavoidable part of CCP clearing. Thus, policymakers intent on incorporating CCP clearing into the regulatory response to the financial crisis need to recognise and confront this category of problems as part of the process of designing new legislation.

However, these drawbacks need to be distinguished from a second and distinct type of challenge which relates to the technical implementation of the reform rather than to the inherent legal capacity of the underlying device. There are several difficult and pressing challenges of this nature facing policymakers, a good example of which is the global coordination of reform. As has been recognised by many of the parties involved, it is going to be essential to coordinate new rules mandating CCP clearing across different jurisdictions (for example, as to the defined terms framing the clearing requirement in each case), as the OTC derivatives markets are sophisticated, cross-border, and adept at seeking opportunities for regulatory arbitrage.

The thesis of this paper is that the challenges relating to regulatory arbitrage and conflicts of law are complex and pressing but of a different quality than those arising from the capacity of CCP clearing per se. Similarly, decisions about where CCPs should be located, ${ }^{130}$ or the regulatory methods that are most appropriate for the potentially diverse class of non-clearable contracts turn on issues which are different from those flowing from the mechanics of CCP clearing itself. This distinction between challenges relating to technical implementation and those relating to legal capacity is significant, principally because the former are challenges which, in an ideal world, could be pre-empted by regulatory coordination and the careful drafting of new rules, whereas the latter are not.

As this analysis makes clear, both these sets of challenges need to be addressed in the process of implementing the CCP prescription. Both have come up in the global debates in one form or another, but there are advantages in differentiating between them. Not least, this approach allows the debate to be ordered in a more systematic way, which is preferable to policymakers attempting to address qualitatively different issues all together and across multiple forums simultaneously.

\footnotetext{
${ }^{130}$ Currently, there are divergent views about whether it will be necessary as part of the CCP prescription to require CCPs to be based in particular locations. For example, the Turner Review argues that the European Commission's proposal that there needs to be a CCP in the Euro zone is 'unnecessary for financial stability reasons'. Turner, n 6 above, 83 .
} 
How this framework may apply in practice varies depending on the stage of the debates, and it also has potential as a means with which to critique eventual draft, primary or secondary, legislation on this issue. One suggestion is that the framework could be used to organise the process of producing draft legislation as follows: as the challenges relating to technical implementation need to be preempted and most obviously require international cooperation, these should be regarded as 'first order' issues for national and international authorities (including IOSCO and CPSS) to address in a coordinated way and as a priority. Given that the CCP prescription will only be effective if these issues are addressed, authorities should regard these matters as pre-conditions for a separate round of discussion addressing the inherent challenges relating to the legal capacity of CCP clearing, which could be held in closer consultation with the CCP industry and users of clearing services themselves. Thus, the different qualities of the challenges relating to legal and technical implementation issues would be recognised, and policymakers would be afforded the opportunity to address each effectively rather than in an ad hoc way.

\section{CONCLUSION}

This is a significant moment in the history of financial regulation. As MacNeil and O'Brien put it, the public sector's rescue of the banking system has meant that the 'power and influence of government within the regulatory matrix has been augmented considerably'. 131 As shown in this paper, the OTC derivatives sector has become a target for duly empowered national and international authorities, and the CCP prescription for the OTC derivatives market has accumulated a good deal of momentum behind it. However, implementing these proposals has sparked a complex and transnational debate which has not yet yielded finalised legislation (outside the US) or precise rules about how the mechanism will work in practice (even in the US). The argument that I have made in this paper is that within these debates greater recognition should be paid to the fact that CCP clearing is first and foremost a private sector legal device, constructed from private law techniques to serve the market.

From this starting point, I have argued that the debate about implementing the CCP prescription by means of new legislation would be advanced if the private law techniques underpinning it were acknowledged clearly and in detail. Amongst other benefits, this helps to isolate limitations built into CCP clearing from those challenges relating to the technical implementation of the reform. Systematising the questions of detail thrown up by this reform would, I have argued, be a constructive step towards effective primary and secondary legislation.

${ }^{131}$ I. MacNeil and J. O’Brien, 'Introduction' in MacNeil and O’Brien (eds), n 62 above, 1. 
It is in many ways disappointing that a proposal like the CCP prescription should start off with so much high-profile support but nonetheless become so bogged down in technical detail. Importing a regulatory solution from the private sector has likely proved more controversial than advocates expected - there are still vitally important questions about the reform which are unresolved, after two years of discussions. But a private law analysis at least helps to make sense of it all by showing where the complexity comes from the legal mechanics of CCP clearing and where it does not. 